Dr. Stadler András ${ }^{1}$

\title{
A Magyar Honvédség feladatai és értéktartalma a COVID-19 járvány okozta különleges jogrendben DOI 10.17047/Hadtud.2021.31.E.29
}

A tömeges megbetegedést okozó humánjárvány, vagy járványveszély civilizációs eredetü veszély, mely indokolttá teheti a különleges jogrend bevezetését. A veszélyhelyzetet a különleges jogrendi esetek közül általánosságban a "legenyhébb" következményeket kiváltó tényállásként szokták titulálni, azonban évekig is elhúzódhatnak annak hatásai. A szerző kísérletet tesz bemutatni a Magyar Honvédség veszélyhelyzeti feladatait a COVID-19 világjárvány első hullámának tapasztalatai alapján.

KULCSSZAVAK: COVID-19, veszélyhelyzet, különleges jogrend, kormányzás, Magyar Honvédség, feladat

\section{Tasks and Achievements of the Hungarian Defence Forces during Special Legal Order Caused by the Covid-19 Pandemic}

\begin{abstract}
Pandemics causing infection of masses, or epidemic risks are threats to civilization, which may necessitate declaring the introduction of special legal order. Despite the fact that among the special legal orders state of danger is constituted as implying the most moderated consequences, they may have long-term effects even lasting for years. The author attempts to introduce the Hungarian Defence Forces' tasks during a state of danger, by taking into account the lessons learned from the first wave of the COVID-19 pandemic.
\end{abstract}

KEYWORDS: COVID-19, state of danger, special legal order, governance, Hungarian Defence Forces, task

\section{Elözmények}

SARS-CoV-2 (severe acute respiratory syndrome coronavirus 2) a neve annak a fertőző humán koronavírusnak, amely a COVID-19 elnevezésű világjárványt okozta 2020. év elején.

A kínai Vuhanban - 2019 végén - új koronavírus jelent meg, mely eredetileg csak állatokat megfertőző vírus volt, de egy úgynevezett homológ rekombináció útján képessé vált arra, hogy átterjedjen az emberre is. Gyakorlatilag az első tünetek - 2019 decemberi jelentkezésétől számított alig több, mint 3 hónap leforgása alatt terjedt szét a világban ez az ismeretlen tüdőgyulladás, amely föleg az idős korosztály esetében nemritkán halált okoz és

\footnotetext{
${ }^{1}$ MH Tartalékképző és Támogató Parancsnokság, Hátországvédelmi Igazgatóság, Katonai Igazgatási Főnökség - Hungarian Defence Forces Territorial Defence and Support Command; e-mail: stadler.andras@mil.hu; https://orcid.org/0000-0001-9619-5508
} 
melyet az Egészségügyi Világszervezet (WHO) 2020. március 11-én világjárvánnyá minősített.

Magyarországon 2020. március 4-éig nem regisztráltak új-koronavírussal fertőzött személyeket, de a felkészülés jegyében a Kormány már 2020. januárjában létrehozta a Koronavírus-járvány Elleni Védekezésért Felelős Operatív Törzset (a továbbiakban: Operatív Törzs), melynek feladata a fertózés kiszürése és lokalizálása, valamint az állami szervek feladatainak összehangolása az egészségügyi és járványügyi intézkedések hatékony megszervezésére. Az Operatív Törzs gyakorlatilag a 2020. január 31-én megtartott alakuló ülésétől fogva kezdte meg a járvány által - a világban - kialakult helyzetek és a vírus terjedés elemzését, továbbá az ezzel kapcsolatos intézkedések és ajánlások megfogalmazását.

A koronavírus járvány elleni védekezés feladataiba a Magyar Honvédség $(\mathrm{MH})$ tevékenyen akkor kapcsolódott be, mikor a Kormány 2020. március 11-én a 40/2020. (III. 11.) Kormányrendelettel az ország teljes területére - veszélyhelyzetet - különleges jogrendet hirdetett ki. A tanulmányban célom a konkrét intézkedések bemutatásán túl a különleges jogrenddel kapcsolatosan az elméleti alapvetés is, hiszen az általános és különös rész kettősével lehet csupán teljes a tanulmány.

\section{A Különleges jogrend fogalma}

Till Szabolcs ${ }^{2}$ írja a különleges jogrendről szóló értekezésében, hogy „, a különleges jogrend az állami hatékonyság fenntarthatósága érdekében megvalósitott, átmeneti időre szólóan eltéritett szükségességi és arányossági normarendszer, a jogállamra vetitett végszükség jellegü intézmény. "3 Álláspontom szerint megfogalmazásai nagyon is beszédesek és magyarázóak, hiszen az első mondatban összefoglalt megállapítást a következőképpen bontja ki és magyarázza meg: „A különleges jogrend az alkotmányos szabályozás különös része, a békétöl, általánosabban az állami müködés általános szabályaitól eltérö időszakok bövitett eszköztárú kezelésének joga. A fogalom célrendszere szerint egyrészt a végszükség kategóriájának államszervezeti szintü vetülete, másrészt egyfajta elrettentö eszköztár az alkotmányon alapuló rendszer stabilitásának biztositása érdekében. Az eszközrendszer tartalmi oldaláról vizsgálva: az alkotmányozó maga határozza meg az államszervezetre vonatkozó azon eltérő szabályokat, amelyek arányos eltérési lehetöséget biztositanak a hatalommegosztáson alapuló államszervezeti szabályokhoz képest annak érdekében, hogy a különleges jogrendet kiváltó okra reagálást követöen az állam müködése mielöbb visszaállitható legyen az általános szabályok szerinti rendszerre..."4

Egy különleges jogrendi helyzet bevezetése tehát mindig azt jelenti, hogy az államnak speciális müködési rendje lép életbe az állampolgárok - életének, testi épségének és biztonságának - védelme érdekében, amely azért kerül bevezetésre, mert a normál, mindennapi körülményekben olyan mértékü változás következett be, amelyet csak különleges - az általánostól eltérő - szabályok bevezetésével és alkalmazásával lehet kezelni. Mint a

\footnotetext{
${ }^{2}$ Till Szabolcs honvéd ezredes, a NATO Defense College (Róma) fakultás tanácsadója, a politikatudomány doktora, EU szakjogász

${ }^{3}$ Till 2019, preambulum.

${ }^{4}$ Till 2019, preambulum.
} 
nevéböl is kitünik különleges - a fennálló normál-állapottól eltérö - jogok és kötelezettségek bevezetésével jár. Carl Schmitt német jogász, filozófus szerint az állam bármit megtehet különleges jogrendben, még a jogszerüséget is félreteheti, nézeteit ezért sokan szélsőségesnek érzik, gondolatait nem mindenki osztja. ${ }^{5}$ Így gondolkodott a különleges jogrendröl: „A politikai prémium a nyugodt és normális idökben viszonylag kiszámitható, abnormális helyzetben teljesen kiszámithatatlan és beláthatatlan. Mindig három részböl áll. Elöször is olyan meghatározatlan és megitélés szerinti fogalmak konkrét magyarázatából és kezeléséböl áll, mint „,közbiztonság és közrend”, ,,veszély”, ,,szükségállapot”, ,, szükséges intézkedések”, „,állam- és alkotmányellenesség”, ,,békés meggyöződés”, ,,létfontosságú érdekek”. Az ilyen fogalmaknak megvan az a sajátosságuk, hogy közvetlenül az adott szituációhoz kötödnek, hogy konkrét tartalmukat csak a konkrét alkalmazás által nyerik el. Másodszor az államhatalom legális birtokosának az oldalán áll a legalitás védelme a kétséges esetekben. Végül harmadszor, az állam minden rendelete kétséges legalitás esetén is azonnal végrehajtható..."6

Fontos megjegyezni, hogy a többlet kötelezettségek és/vagy jogok bevezetése a haladéktalan intézkedéseket hivatott biztosítani és csak ideiglenesen maradnak érvényben, a normál működés visszaállításának elősegítése érdekében. Megnevezése, gyakorlata és fajtái országonként eltérőek, így nincs egységes, minden nemzet által elfogadott definíciója.

Magyarország Alaptörvénye szerint hat különleges jogrendi helyzetet különböztetünk meg, ezek a következők:

- Rendkívüli állapot

- Megelöző védelmi helyzet

- Váratlan támadás

- Szükségállapot

- Terrorveszélyhelyzet

- Veszélyhelyzet

Rendkívüli állapot, megelőző védelmi helyzet és váratlan támadás esetén valamilyen külső, általában fegyveres veszély, fenyegetés vagy szövetségi kötelezettség meríti ki az alkotmányos tényállást. Ezeket nevezhetjük klasszikus, honvédelmi jellegű különleges jogrendi helyzeteknek, hiszen a tényállások elhárításában elsősorban a Magyar Honvédség és a katonák játsszák a főszerepet.

A szükségállapot (belső társadalmi konfliktus), a terrorveszélyhelyzet (külső/belső terrorveszély), veszélyhelyzet (katasztrófa) esetében a kialakult helyzetek elhárítása kapcsán nem a Magyar Honvédség a feladatok fó végrehajtó szerve, tehát ezek nem tekinthetőek honvédelmi jellegünek.

A különleges jogrendi helyzetekről általánosságban elmondható, hogy az állam életének olyan időszaka, melynek során - az Alaptörvényben meghatározott feltételek megléte esetén -

\footnotetext{
${ }^{5}$ Schmitt elméletének legnagyobb kritikusa az olasz Giorgio Agamben. lásd: Bódi 2018, 287-298.

${ }^{6}$ Schmitt 2006, 42.
} 
kivételes hatalom gyakorolható, amely jelentheti a törvények felfüggeszthetőségét /korlátozhatóságát/hatályon kívül helyezhetőségét, a rendeleti kormányzás bevezethetőségét és az operatív intézkedés lehetőségét.

Különleges jogrendben még az alapvető jogok gyakorlása is - az Alaptörvényben megállapított sérthetetlen alapvető jogok kivételével - felfüggeszthető vagy korlátozható, azonban az Alkotmánybíróság müködése nem korlátozható és az Alaptörvény alkalmazása nem függeszthető fel.

A különleges jogrendben alkalmazandó részletes szabályokat sarkalatos törvények határozzák meg és közös szabály, hogy a bevezetésre jogosult szerv megszünteti, ha kihirdetésének feltételei már nem állnak fenn.

\section{A veszélyhelyzet bemutatása}

Figyelmünket a veszélyhelyzetre ${ }^{7}$ irányítjuk a továbbiakban, hiszen a járvány kapcsán ennek kihirdetésére került sor.

Muhoray Árpád ${ }^{8}$ szerint Magyarország lakosságának biztonsága érdekében a természeti és civilizációs katasztrófák elleni védekezés a védelmi igazgatás szereplőinek közremüködésével valósítható meg. A katasztrófavédelmi igazgatás és a védelmi igazgatás összefüggéseit a modern külföldi szakirodalom kevésbé komplexen dolgozza fel. ${ }^{9} \mathrm{~A}$ katasztrófavédelmi igazgatás kérdését mértékadóan többen vizsgálták disszertációkban, publikációkban, jegyzetekben ${ }^{10}$, azonban az ő munkásságuk sem terjed ki részletesen a veszélyhelyzetek kihirdetése esetén a védelmi igazgatás konkrét közigazgatási feladataira. Muhoray szerint, egy újfajta megközelítés volna szükséges a katasztrófavédelmi igazgatás és a védelmi igazgatás vizsgálatára a veszélyhelyzetek kihirdetését igénylő természeti és civilizációs katasztrófák elleni védekezés során a jogalkotási fejlődés igazolása és a további módosítási javaslatok megfogalmazása céljából. Álláspontja szerint a tudományos probléma abban is megfogalmazható, hogy a közigazgatás és a szakma képviselői sem érzékelik mindenkor, hogy a katasztrófák következményei káros hatásának csökkentése hatékonyan csak a katasztrófavédelmi és a védelmi igazgatás szereplőinek szoros együttműködésében valósítható meg, amelynek meghatározó fázisa a különleges jogrend, a veszélyhelyzet kihirdetésének időszaka. ${ }^{11}$

\footnotetext{
${ }^{7}$ A veszélyhelyzet, Alaptörvény, 53. cikk.

(1) A Kormány az élet- és vagyonbiztonságot veszélyeztető elemi csapás vagy ipari szerencsétlenség esetén, valamint ezek következményeinek az elhárítása érdekében veszélyhelyzetet hirdet ki, és sarkalatos törvényben meghatározott rendkívüli intézkedéseket vezethet be.

(2) A Kormány a veszélyhelyzetben rendeletet alkothat, amellyel - sarkalatos törvényben meghatározottak szerint - egyes törvények alkalmazását felfüggesztheti, törvényi rendelkezésektől eltérhet, valamint egyéb rendkívüli intézkedéseket hozhat.

(3) A Kormány (2) bekezdés szerinti rendelete tizenöt napig marad hatályban, kivéve, ha a Kormány - az Országgyülés felhatalmazása alapján - a rendelet hatályát meghosszabbítja.

(4) A Kormány rendelete a veszélyhelyzet megszünésével hatályát veszti.

${ }^{8}$ Muhoray Árpád nyugállományú polgárvédelmi vezérőrnagy gondolatait lásd: Muhoray 2019, 61.

${ }^{9}$ Ezek a publikációk inkább a katasztrófavédelmi szakmai feladatokra fókuszálnak.

${ }^{10}$ Többek között Muhoray Árpád, Schweickhardt Gotthilf, Hornyacsek Júlia, Mógor Judit, Endrődi István, Lakatos László, Kádár Pál, Keszely László, Bárdos Zoltán.

${ }^{11}$ Muhoray 2019, 62.
} 
Lakatos László ${ }^{12}$ szerint a védelmi igazgatás szerepét vizsgálva a katasztrófák elleni védekezésben, a honvédelmi törvény végrehajtási rendeletének (Hvt.vhr.) értelmezö rendelkezéséből célszerü kiindulni. Ez alapján a védelmi igazgatás a közigazgatás részét képező feladat- és szervezeti rendszer, amely a Kormány - a honvédelemért felelős miniszter útján gyakorolt - irányítása mellett a Magyarországot veszélyeztető fenyegetésekkel és támadásokkal szemben az állam feladatainak megvalósítására létrehozott, valamint egyes védelmi feladatok ellátásra kijelölt közigazgatási szervek által végzett tervező, végrehajtó, rendelkező tevékenység. ${ }^{13}$

A korábbi - már hatályát vesztett - magyar jogforrásokból levezethető, hogy a különleges jogrend bevezetését igénylő helyzetek, a korábbi jogi hierarchiában duplikációra adtak lehetöséget, miközben intézményesített súlyosság, gyakoriság vagy területi egység küszöbértéke nem volt megfogalmazva, mivel szükségállapot, illetve veszélyhelyzet is kihirdethető volt az élet- és vagyonbiztonságot tömeges mértékben veszélyeztető elemi csapás, vagy ipari szerencsétlenség bekövetkezése miatt. Súlyosabb természeti katasztrófa esetén szükségállapot, enyhébb esetben veszélyhelyzet, ipari katasztrófánál szükségállapot. Muhoray korábban hivatkozott művében kimondja, hogy a védelmi igazgatási feladatok ellátására a kijelölt közigazgatási szerveknek szükséghelyzetben is fel kellett készülniük, hiszen az 1949. évi XX. törvény - A Magyar Népköztársaság Alkotmánya szerint a jelenleg érvényben lévő Alaptörvény hatálybalépéséig az Országgyülés az élet és vagyonbiztonságot tömeges mértékben veszélyeztető elemi csapás, vagy ipari szerencsétlenség esetén szükségállapotot is kihirdethetett volna. ${ }^{14}$

Ezen gondolat mentén haladva, akár a jelenlegi járványügyi helyzetre is alkalmazható lett volna a szükségállapoti minösítés. A Kormány azonban sem a mostani helyzetben, sem korábban nem tett javaslatot a szükségállapot kihirdetésére az Országgyülésnek.

A veszélyhelyzet Magyarország Alaptörvényében (53. cikk) szabályozott, nem honvédelmi jellegú különleges jogrendi helyzet, részletszabályait a katasztrófavédelemröl és a hozzá kapcsolódó egyes törvények módosításáról szóló - 2011. évi CXXVIII. számú törvény szabályozza. ${ }^{15}$

A veszélyhelyzetet a jelenleg hatályos 2011. évi CXXVIII. számú törvény alapján, különösen a következö események válthatnak ki: elemi csapások, természeti eredetü veszélyek, ipari szerencsétlenség, civilizációs eredetủ és egyéb eredetủ veszélyek. A tömeges megbetegedést okozó humánjárvány vagy járványveszély az utolsó kategóriába sorolt veszély, ezért a Kormány az élet és vagyonbiztonságot veszélyeztető tömeges megbetegedést okozó humánjárvány ${ }^{16}$ következményeinek elhárítása, a magyar állampolgárok egészségének és életének megóvása érdekében Magyarország egész területére veszélyhelyzetet hirdetett ${ }^{17} \mathrm{ki}$ 2020. március 11-én.

\footnotetext{
${ }^{12}$ Nyugalmazott okl. mk. vezérőrnagy, egyetemi docens, c. egyetemi tanár, a Magyar Tudományos Akadémia Gazdaság- és Jogtudományi Osztály Hadtudományi Bizottságának tagja.

${ }^{13}$ Lakatos 2019, 39.

14 Muhoray 2019, 62.

15 A 44.§-tól egészen az 51.§-ig.

16 2011. évi CXXVIII. törvény 44. § c), ca)

${ }^{17}$ A 40/2020. korm. rendelettel.
} 
A Kormány a veszélyhelyzetben tehát rendeletet alkothat, amellyel egyes törvények alkalmazását felfüggesztheti, törvényi rendelkezésektől eltérhet, valamint egyéb rendkívüli intézkedéseket hozhat, azonban mint említettem, az Alkotmánybíróság müködése nem korlátozható és az Alaptörvény alkalmazása nem függeszthető fel. Ez a különleges jogrendi helyzet tizenöt napig marad hatályban, kivéve, ha a Kormány - az Országgyülés felhatalmazása alapján - a rendelet hatályát meghosszabbítja. Ez meg is történt, hiszen az Országgyülés a - koronavírus elleni védekezésröl szóló - 2020. évi XII. törvénnyel felhatalmazta a Kormányt, hogy a járvány idején hozott kormányrendeletek hatályát a veszélyhelyzet megszünéséig meghosszabbítsa és az elhárítása érdekében tett intézkedéseket megerösítse.

A veszélyhelyzet elhárításáért a fő felelős és a hatalmi centrum közvetlen gyakorlója a Kormány, feladatának ellátásában Koronavírus-járvány Elleni Védekezésért Felelős Operatív Törzs segítette. A COVID-19 járványhelyzettel és a veszélyhelyzet kihirdetésével egyidejüleg a Kormánynak nem kellett - az Egészségügyi törvényben ${ }^{18}$ (a továbbiakban: Eütv.) szabályozott - egészségügyi válsághelyzetet ${ }^{19}$ is életbe léptetnie, hiszen különleges jogrend elrendelésével magasabb minősítésű helyzet (jogrend) lépett életbe, melyben - a kihirdetéstől függetlenül - alkalmazásra kerülhettek (és kerültek) az egészségügyi válsághelyzet egyes szabályai is.

Hipotetikus kérdést vet fel, hogy vajon milyen belső következményeket eredményez a fent ismertetett állapot tartós idejü fenntartása, hiszen ,a magyar állam müködése a hatalom megosztásának elvén alapszik" ${ }^{20}$, de kérdéses, hogy ez az elv miként tud érvényesülni, ha huzamos időn keresztül eltolódik a végrehajtó hatalom (Kormány) irányába a hatalomgyakorlás. Till Szabolcs Különleges jogrend címü müvében ezt azzal magyarázza, hogy „a békétöl eltérö időszakok joga mindezen eltérési lehetöségek mellett is csak az alkotmányosság fogalomkörében értelmezhető: vannak alkotmányos korlátok és intézmények, különösen az Alkotmánybíróság, amelynek feladata a hatalomgyakorlás feltételeinek betartatása annak érdekében, hogy a visszaélésszerü joggyakorlás ne eredményezhessen az alkotmánystabilitási szereppel összeegyeztethetetlen, önkényesen gyakorolt államhatalmat. A szabályozási elemek így összességében a stabilitás megörzése érdekében eltérést megengedö és a visszaélésszerü joggyakorlással szembeni fellépést megalapozó vészfék típusú elemek dichotómiájára, arányosságára építenek, egy demokratikus államban szükséges jogkorlátozások eltérö standardjait eredményezve." 21

Álláspontom szerint az alkotmányos korlátok (fékek) és intézmények csak abban az esetben tudnak megfelelő garanciát és féket nyújtani a "privilegizált" joggyakorlással és egy esetleges visszaélésszerü államhatalom gyakorlással szemben, ha a rendeltetési célok érdekében, jogszerüen müködnek. Továbbá véleményem szerint ez még mindig nem ad megfelelő választ az időtényezőre, miszerint meddig nem okoz visszafordíthatatlan torzulást az állam belső működésére a hatalom - egy hatalmi ág irányába történő - nagymértékü

\footnotetext{
18 1997. évi CLIV. törvény az egészségügyről

${ }^{19}$ Eütv. 228.§-tól 232. §-ig.

${ }^{20}$ Alaptörvény C) cikk (1) bekezdés.

21 Till 2019, 3.
} 
eltolódása. A kérdések létjogosultságát erősíti, hogy a rendeleti kormányzás 15 napos időbeli hatályának meghosszabbítása is Alaptörvényben foglalt lehetőség, és a végső korlát csak a veszélyhelyzet megszűnése. ${ }^{22}$ A 15 napos időkorlát - Alaptörvényi rendelkezése - a normál müködési rend mielőbbi visszaállítását szolgálja, melynek meghatározásakor alapvetően a korábbi árvízvédelmi tapasztalatok adtak iránymutatást. „Az Országgyülés - az Alaptörvény 53. cikk (3) bekezdés szerinti - felhatalmazási jogköre megitélésünk szerint a katasztrófavédelemröl és a hozzá kapcsolódó egyes törvények módositásáról szóló 2011. évi CXXVIII. törvény alapján elözetesen adott, így - végső soron - a veszélyhelyzet megszüntetése vonatkozásában a szükségesség fennállásának mérlegelése kizárólagos kormányzati jogkörbe tartozó célszerüségi kérdés. " 23

\section{A Magyar Honvédség érintettsége a COVID-19 járvány okozta veszélyhelyzetben}

\section{A Magyar Honvédség személyi állományát érintö fö rendelkezések}

A koronavírus-járvány világszerte - az emberáldozatok mellett - jelentős gazdasági károkat is okozott és okoz mikro- és makrogazdasági szinten egyaránt. A kedvezőtlen gazdasági környezet Magyarországot sem kímélte a - járvány terjedésének megfékezése érdekében bevezetett korlátozó intézkedések miatt sokan szenvedtek gazdasági károkat és kikerültek a munkaerőpiacról.

A Magyar Honvédség állományába tartozó létszámot ezek a tények nem érintették hátrányosan, sőt a korlátozó intézkedések ebben a tekintetben pont az ellenkező irányba hatottak, hiszen föszabályként érvényesül az a honvédek jogállásáról szóló törvényben ${ }^{24}$ nevesített szabály, hogy a veszélyhelyzet ideje alatt - a hivatásos katonák - egyoldalúan nem is mondhatnak le vállalt honvédségi jogviszonyukról. Az egyoldalú nyilatkozattal történő jogviszony megszüntetés hivatásos állományra alkalmazott szabályait a kiadott 86/2020 Korm. rendelet - a veszélyhelyzet során alkalmazandó egyes honvédelmi tárgyú szabályokról - értelmében - a veszélyhelyzet ideje alatt - a szerződéses katonákra is alkalmazni kell, továbbá a 120/2020. Korm. rendelet - a honvédelmi szervezetek személyi állományára a veszélyhelyzet ideje alatt alkalmazandó egyes eltérő szabályokról - ezt a rendelkezést kiterjesztette az önkéntes tartalékos állományra és a honvédelmi alkalmazottakra is.

A veszélyhelyzet során számos új feladat képeződött az egészségügyi, rendvédelmi, honvédelmi és politikai (elsősorban kormányzati) szinteken. Ezen feladatok koordinálása a védelmi igazgatás hatáskörébe tartozik. A védelmi igazgatás a közigazgatás sajátos, speciális területe, amely - mint szervezet- és feladatrendszer - magában foglalja Magyarországot és annak lakosságát fenyegető valamennyi veszéllyel szembeni védekező tevékenységet, ezek tervezését, szervezését és végrehajtását. „E körbe nem csupán a honvédelem vagy rendvédelem kérdései tartoznak, hanem tágabb értelemben ide soroljuk a lakosságvédelem, az egészségvédelem, a gazdaságvédelem és más, az állam normális müködését veszélyeztetö jelenségekkel szembeni fellépést, például a kibervédelmet is. Nincs külön békeidejü, és

\footnotetext{
22 Alaptörvény 53. cikk (4).

${ }^{23}$ Till 2019, [24].

24 A 2012. évi CCV. törvény 61. § (3) bekezdés b) pont szerint.
} 
különleges jogrendben müködö védelmi igazgatás. A védelmi igazgatás szervezetrendszere »békeidőben« is létezik, müködik, és végrehajtja a normális müködés szerinti feladatait. Ebben az idöszakban van lehetöség a különleges müködésre vonatkozó tervek, eljárásrendek, jogszabályok kidolgozására, a szükséges feltételek megteremtésére, a várható feladatok, és a más szervekkel való együttmüködés begyakorlására. Különleges jogrendben azonban már a végrehajtásé a föszerep, vagyis itt már a rendelkezésre álló szervezeti keretekben, a megteremtett feltételekkel, a kidolgozott tervek alapján, a védekezésben részt vevö más szervekkel a lehetö leghatékonyabban együttmüködve kell mielöbb elháritani a veszélyt. Az alapvetö különbség tehát békeidejü és különleges jogrendi müködés között elsősorban a végrehajtandó feladatokban, és a végrehajtás tempójában van. A minél gyorsabb, de mégis megalapozott döntéshozatalt a védelmi igazgatási szerveknél létrehozott operatív csoportok, elöre kidolgozott tervek szerint megalakitott döntés elökészitö törzsek segitik" 25.

A Magyar Honvédség - kialakult helyzetben realizálódott - új-koronavírussal kapcsolatos feladatrendszere jelentősen eltért a megszokott, békeidőszaki feladataitól annak érdekében, hogy továbbra is szavatolja a magyar lakosság biztonságát. Ennek érdekében a fentebb már említett 120/2020. Korm. rendelet a heti (40 óráról 60 órára) és a napi (8 óráról 12 órára) szolgálatteljesítési időkorlátot - túlszolgálati ellentételezés nélkül - felemelte.

Szintén a honvédségi többletfeladatok ellátásának szavatolását támogatták a különböző kormányrendeletekben és $\mathrm{MH} \mathrm{PK}^{26}$ intézkedésekben/parancsokban foglalt az önkéntes tartalékos állományt érintő rendelkezések. Ezek az új szabályzók lehetővé tették számukra, hogy behívásuk idejére a szerződéses/hivatásos állományhoz hasonló juttatásokra legyenek jogosultak (pl. fokozott igénybevételi pótlék), azonban ki kell emelni, hogy az előző bekezdésben taglalt - heti és napi szolgálatteljesítési időkorlát felemelése (túlszolgálat ellentételezése nélkül) - rendelkezések az állandó állomány járandóságainak csökkentését is jelentette. A veszélyhelyzet elrendelésével életbe lépett az önkéntes tartalékosok behívásával kapcsolatos, rövidebb határidőt lehetővé tevő jogi normák alkalmazása ${ }^{27}$.

Magyarország katonai alakulatai szükséges mértékben aktivizálták a müveleti vezetési rendszer elemeket a járványügyi helyzettel kapcsolatos feladatok ellátására, melyek - nem ritkán 24 órás - folyamatos, váltásos munkarendben látták el a keletkező műveletek koordinációs, tervező, szervező és végrehajtó feladataikat.

A COVID-19 járvány - országos - terjedésével a Magyar Honvédség objektumaiban és a személyi állomány tekintetében a parancsnokok intézkedéseikkel - az Operatív Törzs és az MH egészségügyi főnökének irányelvei alapján, a Magyar Honvédség Parancsnokának feladatszabása szerint - folyamatosan szigorítottak a járványügyi óvintézkedéseken és higiéniás rendszabályokon, melynek érdekében számos korlátozó rendelkezés született (pl. beléptetés, rendezvények betiltása, lázmérés, kényszerszabadságoltatások, külföldi utazás tiltás stb.)

\footnotetext{
25 Varga Attila Ferenc ezredes, a Honvédelmi Minisztérium Védelmi Igazgatási Főosztály vezetőjének gondolatai: Varga 2020, 1.

26 A Magyar Honvédség Parancsnoka.

27 9/2013. (VIII. 12.) HM rendelet 254. § (3)
} 
Dr. Benkő Tibor honvédelmi miniszter - Miniszterelnöki feladatszabás alapján - 2020. május 19-én bejelentette, hogy a Magyar Honvédség 5000 fó átmeneti foglalkoztatásával vállal szerepet a kormány válságkezelő programjában. A munkahelyteremtés a Kormány gazdaságvédelmi akciótervének kiemelt eleme, melyben az MH - ettől az időponttól kezdődően - jelentős szerepet vállal.

Az MH munkahelyteremtése olyan módon valósult meg, hogy a már müködö önkéntes területvédelmi tartalékos elem meglévő kereteit némileg átalakította és egy speciális önkéntes tartalékos katonai szolgálati formát vezetett be, melynek célközönsége és toborzási bázisa a koronavírus-járvány következtében munkáját vesztett magyar állampolgárok.

Az MH-nak ezzel a lépéssel is szándékában áll megteremteni annak lehetőségét, hogy aki katonai szolgálatot kíván vállalni, az minden erre vonatkozó támogatást megkapjon.

Az új speciális szolgálati forma elsősorban katonai alapkiképzésre és egyéb katonai képességek elsajátítására épül, mely havi rendszerességü illetményt nyújt azoknak a jelentkezőket, akik megkezdik az ilyen irányú szolgálatukat.

A speciális szolgálati forma bevezetése az MH részére is kedvező, hiszen abban az esetben is bővíti Magyarország kiképzett tartalékos ${ }^{28}$ állományát, ha az adott állampolgár a kiképzéseket követően elhagyja a Magyar Honvédséget és visszailleszkedik a "civil munka világába". Kiemelendő továbbá, hogy a speciális önkéntes tartalékosok kiképzésével nő a polgárok honvédelmi ismerete és ezzel együtt az önvédelmi képessége is. Fontos megemlítenünk, hogy a Honvédelmi törvény - egyel fentebb hivatkozott - rendelkezése alapján, női jelentkezők nem lehetnek kiképzett tartalékosok, de kiképzésükkel a társadalomra gyakorolt pozitív hatás tovább növekedhet, melyet külön is érdemes lenne - a majdani tapasztalatok alapján - megvizsgálni.

\section{A Magyar Honvédség fö feladatai veszélyhelyzetben}

A Magyar Honvédség alapfeladata veszélyhelyzetben, hogy közremüködik a különleges jogrend idején kiadott rendeletek, intézkedések, továbbá az egészségügyi/rendészeti /katasztrófavédelmi szervek feladatvégrehajtásába, amennyiben azok saját erőforrásai nem elegendőek a különleges jogrend elrendelését kiváltó ok megakadályozására, elhárítására.

A veszélyhelyzet feladataiba klasszikusan a saját Honvédelmi Katasztrófavédelmi Rendszerén (HKR) keresztül kapcsolódik, föszabály szerint elsődlegesen a HKR-ben meghatározott, megfelelően felkészített készenléti erők kerülhetnek alkalmazásra a különleges jogrendi feladatokba. Jelen esetben a katonai szervezetek nem rendelkeztek a végrehajtandó feladatra HKR kijelölt készenléti erővel, ezért a COVID-19 járványügyi helyzet miatt a HKR nem került aktivizálásra.

A COVID-19 vírus miatt elrendelt különleges jogrend egy olyan speciális veszélyhelyzet elrendelését vonta maga után, mely a materiális környezetünkben nem idézett elő változást, hiszen a vírus - láthatatlan terjedésével - elsősorban az egészségügyi szerveket, valamint az egészségügyi tevékenységet ellátó személyeket állította rendkívüli kihívások és feladatok elé.

\footnotetext{
${ }^{28} 2011$. évi CXIII. törvény (Hvt.) 41. § (4) A kiképzett tartalékos állomány a Honvédség állományából kikerült korábban.

a) hivatásos, szerződéses, önkéntes tartalékos vagy b) katonai tanintézetben alapkiképzést teljesített hallgatói, honvéd tisztjelölti vagy altisztjelölti szolgálatot teljesített férfi tartozik.
} 
A veszélyhelyzet kihirdetésével keletkező komplex feladatokon felül a Magyar Honvédségnek a hagyományos alaprendeltetését is be kell töltenie, így továbbra is biztosítania kellett/kell Magyarország területi integritását, függetlenségét, a magyar emberek szabadságát és biztonságát.

Korridor feladat

A Magyar Honvédség személyi állománya 2020. március 12-től részt vett az úgynevezett „Korridor” feladatban, ami azt jelenti, hogy Magyarország nagy tranzitforgalmat bonyolító autópályáinak (M1, M5 és M7 autópályák) kijelölt csomópontjaiban és pihenőhelyein, statikus és mozgó járőrökkel segítették a rendőrség munkáját (humanitárius folyosó biztosítása). Fő feladatuk volt, hogy a Magyarországon áthaladó tranzit utazók (pl. szállítmányozási célból, külföldről érkező kamionok) a számukra kijelölt útvonalakról ne térjenek le, ezzel is csökkentve az érintkezés lehetőségét a magyar lakossággal. Ezen felül jelenlétükkel fokozták a polgári lakosság biztonságát, a közrend megóvását és egyben ellenőrzést hajtottak végre annak érdekében, hogy a felfrissülni vágyó járművezetők csak a kijelölt pihenőkben álljanak meg, továbbá a járványügyi szabályokat betartva viselkedjenek.

Külföldi missziók helyzete

Számtalan külföldi missziós szolgálatot érintett az új-koronavírus hatása. A Magyar Honvédség erőinek és kritikus képességeinek megőrzése elsődleges fontosságú, ezért akadtak olyan missziók, ahonnan a COVID-19 járvány terjedésével ki kellett vonni a személyi állomány egy részét, vagy egészét.

Az Európai Unió (a továbbiakban: EU) védelmi minisztereinek nagyrésze, 2020. április 06-án, video-telekonferencia ülésen tárgyaltak a COVID-19 járvány békeműveletekre gyakorolt hatásairól és az EU egyes nemzeti haderőinek vírus elleni küzdelemben folytatott szerepéről (Magyarországot Szabó István honvédelmi ügyekért felelős államtitkár képviselte).

Megállapíthatjuk, hogy „az Európai Unió létrejöttével a szuverenitás és a jogalanyiság kategóriái a korábbiakhoz képest megváltozott tartalommal élnek tovább, e folyamatok mozgatói az Európában végbement események voltak, amelyekre a kontinens államai újszerünek számító választ adtak, az Európai Közösségek, majd az EU létrehozásával. "29

A konferencián alapvető megállapítást nyert, hogy az EU békefenntartói tevékenységére az eddigieknél is nagyobb szükség van/lesz a járvány idején és azt követően, különösen a már jelenleg is "sérülékeny", kevésbé "stabil" országokban, valamint régiókban. Ezért a jelenlevők megerősítették az EU misszióinak jelenlét fenntartását.

Közös Akarat COVID 2020 és a határvédelmi feladat

A tömeges bevándorlás okozta válsághelyzet, vagy más néven a migrációs válsághelyzet fogalmát Magyarországon a menedékjogról szóló 2007. évi LXXX. törvény 2015. évi módosítása vezette be. ${ }^{30}$

\footnotetext{
${ }^{29}$ Knapp 2015, 322.

30 2015. szeptember 4-én szavazta meg az országgyülés, a kormány nevében Pintér Sándor belügyminiszter által elöterjesztett javaslat alapján.
} 
„A tömeges bevándorlás okozta válsághelyzetet az országos rendörfökapitány és a menekültügyi hatóság vezetöje kezdeményezésére, a miniszter javaslatára a Kormány rendeletben rendelheti el. A tömeges bevándorlás okozta válsághelyzet Magyarország egész, illetve annak meghatározott területére rendelhetö el." 31

2020 február végén az EU számára is világossá vált és a török kormány be is jelentette, hogy Törökország nem bírja tovább a migrációs nyomást és "megtelt". A menekültpolitikájukat továbbra is fenntartják, de már nincsenek abban a helyzetben, hogy fel tudják tartóztatni - a túlnyomóan szír, iráni, iraki, marokkói és pakisztáni bevándorlókból álló - újabb menekülthullámokat.

Ezek hatására a magyar határon is várhatóvá vált az illegális határátlépési kísérletek számának növekedése, továbbá a migránsok körében is feltételezhetővé vált a COVID-19 megbetegedések megjelenése. A fokozódó körülményekre való tekintettel - 2020. március 06-án - a Kormány Magyarország egész területére - újabb 6 hónapra - meghosszabbította a tömeges bevándorlás okozta válsághelyzetet. ${ }^{32}$

Mint már említettem, a járványügy számos új feladatot delegált a különböző rendvédelmi szervek állománya számára, így különösen a Rendőrség számára. A Belügyminisztérium (BM) tehermentesítésére (a Rendőri erők a járványügyi helyzet kapcsán más feladatokra kerültek átcsoportosításra) az MH, 2020. március 12-től több, mint száz fővel növelte Magyarország déli határán szolgálatot teljesítő katonáinak létszámát, akik folyamatos jellemzően két hetes - turnusváltásokkal látták el határvédelmi feladataikat a veszélyhelyzet ideje alatt.

A vírus terjedésével és annak megfékezésére, Magyarország északi és nyugati határszakaszain is visszaállításra került a határellenőrzés, ezzel egyidejüleg a Készenléti Rendőrség a déli határvédelmi - Közös Akarat - feladatba beosztott állománya átcsoportosításra került a közúti határátkelőhelyek és egyéb feladatok végrehajtására.

Magyarország és az Európai Unió határainak biztosítása érdekében, így az északi és nyugati határokon is biztosítani kellett $\mathrm{MH}$ részvételét a határörizetben. Az északi határforgalmi korlátozások és zárási feladatok biztosítására az $\mathrm{MH}$ telepített határzárakkal 2020. március 21-től - nyújtott támogatást a BM erők határvédelmi feladataiba, így a szlovén, szlovák és osztrák határokon, egyszerre több mint 100 magyar katona vett részt folyamatosan - a feladatok ellátásában.

Egyetértek Bódi Stefánia és Szuhai Ilona migrációs válsághelyzetet taglaló elemzésében foglaltakkal, melyet már 2016-ban megfogalmaztak: „A tömeges bevándorlás okozta válsághelyzetet célszerü lenne beilleszteni a különleges jogrend esetei közé az Alaptörvénybe." ${ }^{133}$ Azóta több, mint 4 év telt és egy új különleges jogrendi tényállással bővült az Alaptörvény, azonban nem a tömeges bevándorlás okozta válsághelyzettel, hanem a terrorveszélyhelyzettel. ${ }^{34}$ Van némi kapcsolódási pont a két fogalom tartalmi lényege között, de alapvetően külön-külön is szerepelhetnének a minősített jogrendek alaptörvényi szintjén (a

\footnotetext{
31 2007. évi LXXX. törvény 80/A. § (2) bekezdés.

${ }^{32}$ A 41/2016. (III. 9.) Korm. rendelet módosításával

${ }^{33}$ Bódi - Szuhai 2016, 45.

${ }^{34} \mathrm{Az}$ Alaptörvény hatodik módosításával, 2016. június 7-én az Országgyülés kiegészítette a különleges jogrendre vonatkozó szabályozást a terrorveszélyhelyzet kategóriájával.
} 
jelenlegi Alaptörvény felépítésében). Ettől függetlenül vannak olyan vélemények, hogy elegendő lenne egy, vagy maximum kettő különleges jogrendi tényállásban maximalizálni a minősített jogrendet, amivel személy szerint én még jobban tudnék azonosulni, de ehhez átfogó/komplex jogszabály módosításokra lenne szükség és az Alaptörvény különleges jogrendre vonatkozó részét is teljesen át kellene strukturálni. Ezen cél elérése érdekében az egész eddigi koncepciót át kellene alakítani, és az alacsonyabb jogforrási szintek teljes megreformálására is szükség lenne a téma tekintetében.

Jelenlétfokozó, katonai rendészeti járör feladat

A különleges jogrendi veszélyhelyzetre való tekintettel, 2020. március 20-ától, az ország több pontján (15 helyőrségben: Budapest, Debrecen, Hajdúhadház, Szolnok, Hódmezővásárhely, Szentes, Kecskemét, Szeged, Kaposvár, Székesfehérvár, Tata, Várpalota, Győr, Pápa, Veszprém) katonai rendész járőrök kezdték meg jelenlétfokozó szolgálatukat.

A szolgálat elsődleges célja a lakosság biztonságérzetének, valamint bizalmának növelése, a katonai erők láthatósága, ezáltal a közbiztonság, közrend fenntartásának támogatása és az esetleges pánikkeltést megakadályozása volt. A feladatba történő bevonásuk létjogosultságát növelte, hogy a Kormány - 2020. március 28-án, a 71/2020. számú Kormányrendeletében ${ }^{35}$ kijárási korlátozást lépett életbe Magyarország területén. Katonáink ezt követően - támogatva a rendörök munkáját - elsőként a forgalmas közterületeken segítették az állampolgárokat, felhívták a figyelmüket a rendeletben foglaltak betartására és támogatták a rendszabályok foganatosítását.

Honvédelmi Irányító Törzsek és kórházparancsnoki feladatok

Dr. Benkő Tibor honvédelmi minisztert nevezte ki a Kormány - a március 13-án megalakult Létfontosságú Magyar Vállalatok Biztonságáért Felelős Akciócsoport vezetöjének, mellyel egyidőben Honvédelmi Irányító Törzsek (HIT) kerültek létrehozásra.

A HIT-ek fő feladata az lett, hogy biztosítsák Magyarország létfontosságú vállalatainak folyamatos múködését, az ország lakóinak ellátásbiztonságát. Céljuk, hogy a veszélyhelyzet ideje alatt szakmai tudásukkal és a Magyar Honvédség eszközeivel szükség esetén segítséget nyújtsanak például logisztikai, teher- és személyszállítási, ellátási, örzés-védelmi vagy biztonsági feladatokban.

Először március 19-én 71 vállalathoz érkeztek irányító törzsek, majd az idő elörehaladtával számos további vállalat került az ország folyamatos müködéséhez nélkülözhetetlen vállalatok listájára. A legfontosabb területek ezek közül a gyógyszeripar, az élelmiszeripar, az energetika és az infokommunikáció, ezekre nagyobb hangsúlyt is kellett fektetni. Többnyire állami tulajdonban lévő cégekről van szó, de önkéntes alapon ”jelentkezett” több magánvállalat is szerepelt a támogatott cégek között.

35 71/2020. (III. 27.) Korm. rendelet - a kijárási korlátozásról. 
A kórházparancsnokról és az egészségügyi készlet védelméről Korm. rendelet ${ }^{36}$ vezette be, hogy az állami fenntartású kórházak élére kórházparancsnokokat rendelt, melyek között vegyesen voltak rendőrök, katonák és katasztrófavédők.

Erre az intézkedésre azért volt szükség, mert veszélyhelyzetben kiemelt fontosságú, hogy egységes vezetés mellett történjen a vírus elleni védekezés, központilag legyen irányítva az anyaggazdálkodás, az anyagfelhasználás és az ellenőrzés. Ennek érdekében, kórházparancsnoki feladatkört a belügyminiszter irányítása alatt az országos kórházföparancsnok koordinálhatja.

A kórházparancsnoknak a járványveszéllyel összefüggő szabályok betartására, és az egészségügyi készlet megóvására vonatkozó javaslatát az egészségügyi intézmény vezetője köteles végrehajtani. A kórházparancsnokok fö feladata az volt, hogy az igényeket, kéréseket, észrevételeket eljuttassák az országos kórház-főparancsnokhoz, aki feldolgozta és megküldte azokat a koronavírus-fertőzés elleni védekezésért felelős Operatív Törzsnek. A kórházparancsnokok egyfajta közremüködőként, támogatóként voltak jelen, egészségügyi szakmai kérdésben nem dönthettek.

$\mathrm{Az}$ egészségügyi szervek támogatását és tehermentesítését segítette elő a honvédség ROLE-1 típusú katonai sátorrendszereinek telepítése. A kórházak - többnyire - bejáratánál felállított sátorrendszerek a beérkező betegek fogadását, elirányítását, illetve az adminisztratív teendők ellátását tették lehetővé és biztosították a beérkezők közötti megfelelő távolságok megtartását.

Intézmények fertőtlenítése feladat

A vírus - természetéből fakadóan - elsősorban az idős és/vagy valamilyen krónikus betegségben szenvedőket támadja meg, erre tekintettel az idősotthonok lakói fokozott veszélynek voltak kitéve ebben az időben.

Sajnálatos módon a fenti tényt igazolta, hogy például - a Budapesten elhelyezkedő Pesti úti Idősek Otthonában 2020. április 12-éig 198 igazolt koronavírus fertőzöttet diagnosztizáltak és 8 idős ember halálát is okozta a kór.

Az országos tisztiföorvos március 12-én rendelte el a veszélyeztetett korosztályoknak otthont adó szociális intézmények fertőtlenítését, melynek értelmében az MH 93. Petőfi Sándor Vegyivédelmi Zászlóalj Biológiai Mentesítő Csoportja megkezdte a mentesítési feladatit a Pesti úti Idősek Otthonában. A feladat végrehajtását követően még számos másik idősotthon is fertőtlenítésre került, melybe több száz önkéntes területvédelmi és önkéntes müveleti tartalékos katona került bevonásra.

A katonák feladataikat a DS-5, DS-10 és DS-12 mentesítő eszközökkel látták el, melyhez Hypo oldatot, Virkon S port, Virocidot, BX-60 melegköd képző anyagot és MOL Hygi Flow anyagot használtak. A fertőtlenítési feladatok végrehajtásának és a fertőtlenítő eszközök hatékonyságának köszönhetően 800-nál is több intézmény került fertőtlenítésre és az ott lakók már biztonságban érezhetik magukat a vírussal szemben.

36 72/2020. (III. 28.) Korm. rendelet - a kórházparancsnokról és az egészségügyi készlet védelméről. 


\section{Összegzés}

Láthatjuk, hogy „a különleges jogrend gyüjtöfogalmába tartozó esetekben, a hatalomgyakorlás általános szabályaihoz képest új, komplex hatalmi centrum (Honvédelmi Tanács) is létrejöhet, a béke idöszakára szóló hatáskörök pedig módosulnak (Kormány, Köztársasági Elnök) azzal, hogy a korrekció iránya a törvényhozási funkció egyes elemeinek a végrehajtó hatalom felé tolódását is eredményezi. "37 Ez történt most is, hiszen a Kormány irányába, mint alapvetően "végrehajtó hatalom" felé tolódott a hatalmi gócpont, mivel a veszélyhelyzet ideje alatt - Alaptörvényböl fakadó - "törvényhozó hatalmi” jogköröket gyakorolhatott a vizsgált időszak alatt.

A vírus tetőzési időszakát 2020. május első napjaiban érte el, innentől fokozatos csökkenés volt tapasztalható, az új megbetegedések és a - vírus okozta - napi elhalálozások száma lassan, de biztosan csökkenő stádiumba került.

A vírusból történő kilábalás első engedményeiként (könnyítések), előbb vidéken, majd a fővárosban is feloldásra került a kijárási korlátozás, de az egyéni védelemre és személyes higiéniára vonatkozó rendszabályok jórésze máig fennmaradtak.

Magyarország Kormánya 2020. június 18-án megszüntette a magyar állampolgárok egészségének és életének megóvása érdekében elrendelt veszélyhelyzetet. ${ }^{38}$

A veszélyhelyzet kormány általi megszüntetésével hatályát vesztette valamennyi olyan veszélyhelyzet alatt megalkotott kormányrendelet, amely az Alaptörvény különleges jogrendre vonatkozó felhatalmazása alapján került megalkotásra és kihirdetésre. Hangsúlyozandó azonban, hogy a veszélyhelyzet ideje alatt kihirdetett, de az általános törvényi felhatalmazások alapján megszületett kormányrendeletek hatályban maradtak.

A különleges jogrend megszünésével egyidejüleg hatályba lépett az úgynevezett Kivezetési Törvény ${ }^{39}$, mely tartalmazza a járványügyi védekezés következő szakaszának közjogi keretfeltételeit. A törvénnyel az Eütv. már meglévő egészségügyi válsághelyzetre vonatkozó szabályainak kiegészítésével a kormány különleges jogrend fenntartása nélkül szerzett rendeletalkotási felhatalmazást egyes területeken. A felhatalmazás kifejezetten csak a járványügyi védekezéssel kapcsolatos területekre lett kiterjesztve (pl.: szociális távolságtartás szabályai, egészségügyi rendszabályok stb.), az egyéb közügyeket érintő területeken a Kormány már nem élhet a törvényeket felülíró rendeleti kormányzás - különleges jogrendben biztosított - jogosultságával.

A veszélyhelyzet megszüntetésével és a Kivezetési Törvény hatálybalépésével egyidőben, a Kormány Magyarország egész területére az - Eütv. szerinti - egészségügyi válsághelyzet elrendelésével járványügyi készültséget ${ }^{40}$ vezetett be, melynek szükségességét három havonta felülvizsgálja. ${ }^{41}$

Az új jogszabályok megszületésével tehát kijelenthető, hogy a különleges jogrend megszünt, azonban a Kormány az egészségügyi válsághelyzet járványügyi készültségével és

\footnotetext{
${ }^{37}$ Till 2019, 2 bekezdés.

38 282/2020. (VI.17.) Korm. rendelet 1. §.

39 2020. évi LVIII. törvény

${ }^{40}$ Eütv. 228. § (1) ... Egészségügyi válsághelyzet elrendelése járványügyi készültségnek minősül.

${ }^{41}$ A Kormány 283/2020. (VI.17.) Korm. rendelet 1 . § (1), (2).
} 
az átmeneti szabályokkal fenntartott magának olyan jogosultságokat, ami bizonyos területeken biztosítja számára a járványügyi védekezéshez szükséges "privilégiumokat". Egészségügyi válsághelyzet esetén a Kormány - az egészségügy szervezésével és irányításával összefüggő feladatkörében - gondoskodik a veszély elhárításához szükséges feltételek biztosításáról, továbbá ellátja annak elhárítását célzó tevékenységek általános irányítását ${ }^{42}$ (járványügyi intézkedések és szabályok).

Összességében elmondható, hogy ez a típusú - nem honvédelmi jellegü - különleges jogrendi helyzet is számos többletfeladatot idézett elő a Magyar Honvédség számára.

Szubjektív véleményem, hogy ebben az időszakban minden COVID-19-el kapcsolatos feladatba bevont katona és honvédségi dolgozó félre tette az egyéni érdekeit és vállvetve küzdöttek a járvány megfékezésében, hol közvetlenül a "frontvonalnak" számító kórházakban, vagy idősotthonokban, hol - a háttérből - a szervezetekben megalakult operatív csoportokon keresztül. Álláspontom szerint a Magyar Honvédség - képességeihez mérten maximálisan kivette a részét és helytállt a járványügyi helyzetben, tevékenyen hozzájárult a veszélyhelyzet megszünéséhez/megszüntetéséhez.

Elmondható továbbá, hogy a szóban forgó időszak alatt a Magyar Honvédség, alapfeladatához hűen - saját erőinek és kritikus képességeinek megóvása mellett - sikeresen juttatta érvényre a honvédelem értéktartalmát, a honvédelmi érdeket, az adott helyzetben minden rendelkezésére álló képességével kivette a részét a járványügyi feladatokból, az állampolgárok biztonságának és egészségének megóvása érdekében.

$\mathrm{Az}$ önkéntes tartalékos rendszer vonatkozásában is jelentősnek volt mondható a feladatokba történő bevonás és alkalmazás, hiszen különleges jogrendi alkalmazásukra nagyszámban csak a 2013-as Zöldár alkalmával került sor, bár ott jóval nagyobb számban (kb. 1400 fö) teljesítet tényleges szolgálatot. Megjegyzem, hogy az önkéntes területvédelmi tartalékos elemnek ez volt ez első "éles" különleges jogrendi alkalmazása és feladatvégrehajtása, amely a visszajelzések alapján jól működött, és maximálisan megfelelt az alap rendeltetéséből fakadó elvárásoknak.

Álláspontom szerint a tárgyalt időszak alatt nőtt a Magyar Honvédség társadalmi megbecsülése és népszerűsége, az állampolgárok általánosságban pozitívan értékelték a katonák COVID-19-el kapcsolatos feladatokban való részvételét és jelenlétét.

\section{FELHASZNÁLT IRODALOM}

Bódi - Szuhai 2016. Bódi Stefánia - Szuhai Ilona: A civilizációk összecsapása? A tömeges bevándorlás által életre hívott migrációs válsághelyzet elemzése és a különleges jogrend. Hadtudomány, 26. (1-2.): 41-45.

Bódi Stefánia 2018. A különleges jogrend fogalma. In Téglási, András (szerk.): Az állam szervezete. Budapest: Dialóg Campus Kiadó.

\footnotetext{
${ }^{42}$ Eütv. 147. § (1) bekezdés f) pont.
} 
Knapp 2015. Szuverenitás, jogalanyiság, Európai Unió. In Takács, Péter (szerk.): Az állam szuverenitása: eszmény és/vagy valóság: Interdiszciplináris megközelitések. BudapestGyőr: MTA Jogtudományi Intézet, Gondolat Kiadó.

Lakatos László 2019. A honvédelmi típusú különleges jogrendek életbeléptetését igénylő helyzetek és azok korszerü gyakorlati megoldása. In Hornyacsek Júlia: A védelmi igazgatás müködésének gyakorlati tapasztalatai napjaink kihívásainak tükrében. Budapest: Dialóg Campus Kiadó.

Muhoray Árpád 2019. A veszélyhelyzetek kihirdetését igénylő helyzetek és azok korszerü megoldása a gyakorlatban In Hornyacsek Júlia, 61-85. A védelmi igazgatás müködésének gyakorlati tapasztalatai napjaink kihívásainak tükrében. Budapest: Dialóg Campus Kiadó.

Schmitt, Carl 2006. Legalitás és legitimitás. Máriabesnyő-Gödöllő: Attraktor.

Till Szabolcs: „Különleges jogrend” in Jakab András - Fekete Balázs (szerk.): Internetes Jogtudományi Enciklopédia. Letöltés ideje: 2019. $03 . \quad 31$. http://ijoten.hu/szocikk/kulonleges-jogrend

Varga Attila Ferenc: A különleges jogrend és a Magyar Honvédség; Letöltés ideje: 2020. 03. 31. https://honvedelem.hu/cikk/hazai_hirek/a-kulonleges-jogrend-es-a-magyarhonvedseg

\section{JOGFORRÁSOK}

2020. évi XII. törvény - a koronavírus elleni védekezésről

Magyarország Alaptörvénye

2011. évi CXIII. törvény - a honvédelemről és a Magyar Honvédségről, valamint a különleges jogrendben bevezethető intézkedésekröl

2011. évi CXXVIII. törvény - a katasztrófavédelemről és a hozzá kapcsolódó egyes törvények módosításáról

234/2011. (XI. 10.) Korm. rendelet - a katasztrófavédelemről és a hozzá kapcsolódó egyes törvények módosításáról szóló 2011. évi CXXVIII. törvény végrehajtásáról

71/2020. (III. 27.) Korm. rendelet - a kijárási korlátozásról

72/2020. (III. 28.) Korm. rendelet - a kórházparancsnokról és az egészségügyi készlet védelméről

40/2020. (III. 11.) Korm. rendelet - veszélyhelyzet kihirdetéséről

A 2020. évben azonosított új koronavírus (SARS-CoV-2) okozta fertőzések (COVID-19) megelőzésének és terápiájának kézikönyve (Emberi Erőforrások Minisztériuma, Budapest, 2020.)

1949. évi XX. törvény - A Magyar Népköztársaság Alkotmánya

86/2020. (IV. 5.) Korm. rendelet - a veszélyhelyzet során alkalmazandó egyes honvédelmi tárgyú szabályokról 
120/2020. (IV. 16.) Korm. rendelet - a honvédelmi szervezetek személyi állományára a veszélyhelyzet ideje alatt alkalmazandó egyes eltérő szabályokról

81/2020. (IV. 1.) Korm. rendelet - az egészség és élet megóvása, valamint a nemzetgazdaság helyreállitása érdekében elrendelt veszélyhelyzettel kapcsolatos rendkívüli intézkedésekről

282/2020. (VI.17.) Korm. rendelete a 2020. március 11-én kihirdetett veszélyhelyzet megszüntetéséröl

283/2020. (VI.17.) Korm. rendelete a járványügyi készültség bevezetéséről

2007. évi LXXX. törvény a menedékjogról

41/2016. (III. 9.) Korm. rendelet a tömeges bevándorlás okozta válsághelyzet Magyarország egész területére történő elrendeléséről, valamint a válsághelyzet elrendelésével, fennállásával és megszüntetésével összefüggő szabályokról szóló

9/2013. (VIII. 12.) HM rendelet a honvédek jogállásáról szóló 2012. évi CCV. törvény egyes rendelkezéseinek végrehajtásáról

2012. évi CCV. törvény a honvédek jogállásáról 